\title{
Does Love Money Affect Vocational Behavior? Empirical Evidence from Italian Entrepreneurs
}

\author{
Diego Matricano ${ }^{1} \&$ Mario Sorrentino ${ }^{1}$ \\ ${ }^{1}$ Department of Management, Università degli Studi della Campania "L. Vanvitelli", Corso Gran Priorato di \\ Malta n. 1 - 81043 Capua (CE), Italy. \\ Correspondence: Diego Matricano, Department of Management, Università degli Studi della Campania "L. \\ Vanvitelli”, Capua (CE), Italy. E-mail: diego.matricano@unicampania.it
}

Received: March 25, 2019

Accepted: April 30, 2019

Online Published: June 9, 2019

doi:10.5539/ijbm.v14n7p110

URL: https://doi.org/10.5539/ijbm.v14n7p110

\begin{abstract}
The present paper aims to investigate the relevance that love money - i.e. financial resources provided by family, friends, and fools - can have on vocational behavior, standing for personal goals that are occupational in nature. In particular, the relationship between the above-cited financial resources and "core goals" (i.e. the survival of entrepreneurial firms) is tested by leveraging on second-hand data about Italian entrepreneurs retrieved from Global Entrepreneurship Monitor - GEM website and referring to the years 2012-2014 and by applying estimated Logit models.

Achieved results show that financial resources provided by fools do not affect the survival of entrepreneurial firms. On the contrary, financial resources provided by family and friends do it. Noticeably, the impact of financial resources provided by family or by friends varies in terms of intensity and according to entrepreneurial profiles, in particular to gender and age. After highlighting the main limitations of this paper, some hints for further research are proposed in the last part of the paper.
\end{abstract}

Keywords: love money, family/fools/friends, vocational behaviour, survival of firms, entrepreneurial profiles

\section{Introduction}

According to Vondracek et al. (2014, p. 4) "vocational behavior occurs when individuals pursue personal goals that are occupational in nature". The occupational-related goals that individuals try to pursue can be classified in reference to the activity (experiencing satisfaction, original thinking, freedom to make choice), or to the scope or pattern (short- and long-term goals or even lifetime goals). According to the above scholar, a very intriguing and largely investigated kind of occupation-related goals concerns "core goals" (Nichols, 1991; Henderson, 2000) such as founding a successful company, becoming CEO of a company and making it run on the market.

In order to study how individuals try to pursue their occupational-related goals, scholars (Young \& Valach, 2000, 2008; Savickas, 2002, 2005; Valach \& Young, 2004) have proposed and discussed several frameworks. Vondracek and Schulenberg (1986), for example, propose an integrative life-span framework that is based on two main postulates: the conceptual content, concerning the individual in a context, and the propositional content, focused on the related process taking place. Other scholars focus on the relevance of "recursiveness" (Patton \& Mahon, 2006) that strictly refers to dynamic interactions occurring between individuals and systems around them. In this case, interrelationships, mutuality of actions and interactions are the main pillars. Eventually, Bright and Pryor (2011) propose the chaos theory of career. This theory considers several factors that might affect vocational behavior and tries to apply non-linear algorithms in order to foresee the vocational behavior of individuals.

As underlined by Vondracek et al. (2014, p. 7), all the above frameworks "include a system perspectives on person and environment, although different terminology is used to describe them". From the above, it results that it is always necessary to consider the environment in which individuals act and, thus, the influence that external factors can have on their choices in order to investigate occupational-related goals. This assumption is always true, but is even truer when scholars investigate "core goals" (Nichols, 1991) that are related to entrepreneurship - and so they refer to the launching and managing a firm - and that, by definition, refers to a process that is affected by external factors (Busenitz \& Lau, 1996; Busenitz et al., 2000; Mitchell et al., 2000, 2002; Mueller \& 
Thomas, 2001; George \& Zahra, 2002).

In reference to the influence that external factors can have on entrepreneurs, a topic that still seems to be underexplored concerns the impact that love money - briefly defined here as the financial resources provided by family, friends, and fools (Ang, 1991, 1992; Brinlee et al., 2004; Austin et al., 2006; Kotha \& George, 2012; Frid, 2014; Au et al., 2016; Bellavitis et al., 2017; Sieger \& Minola, 2017) - can have on vocational behavior.

Theoretically, love money falls in the group of financial resources since they are funds to be invested. Actually, this is only a myopic view. Love money, in fact, depends on the investor-entrepreneur relationship. This relationship is based on trust and determines an informal exchange of financial resources (Aldrich \& Zimmer, 1986; Ehrlich et al., 1994; Steiner \& Greenwood, 1995; Sapienza \& Korsgaard, 1996; Shane \& Cable, 2002; Au et al., 2016). Reasonably, the investor-entrepreneur relationship might affect subsequent choices made by the former ones and, in particular, it might affect their entrepreneurial involvement. According to this, the research question posed herein concerns if and to what extent love money (depending on a relationship and determining an exchange) affects vocational behavior.

In order to try to respond to the above research question, the paper is structured as follows. In section 2, an extensive review of the investor-entrepreneur relationship is carried out in the light of exchange theory (Homans, 1958; Blau, 1964; Emerson, 1976; Cropanzano \& Mitchell, 2005). The aim of this review is to hypothesize if and how exchanges between investors and entrepreneurs can impact vocational behavior. In particular, in section 3 , the framework rooted in the exchange theory is depicted. Independent variables are the funds provided by family, friends, and fools. The dependent variable is the survival of the company since this can be considered as a proxy of entrepreneurs' involvement and of vocational behavior. In order to improve the statistical robustness of the proposed framework, some control variables are included. In particular, they refer to intellectual capital hold by entrepreneurs. In section 4, estimated Logit models are elaborated through SPSS and empirical results are presented. Since it is an explorative study, the analysis is focused on Italy over a three-year time span (2012-2014). In section 5, after discussing empirical results, some speculations about the impact that love money can have on vocational behavior are presented.

\section{Literature Review: The Social Exchange Theory}

Exchange theory assumes that exchanges of resources are events depending on the relationships established between two or more subjects (Cropanzano \& Mitchell, 2005; Huang \& Knight, 2017). More specifically, exchanges are transfers of resources. As such, they are discrete events that take place over a relationship that, instead, is a tie based on commitments and expectations between two or more subjects. An exchange-based model can begin with relationships or exchanges (Huang \& Knight, 2017). What matters the most is that relationships are at the basis of exchanges whose results flow back into a relationship and modify it (Cropanzano \& Mitchell, 2005). This means that exchanges and relationships nurture each other.

At this stage, it seems appropriate to define relationships and exchanges in a more detailed way. In particular, attention is focused on the dimensions of relationships and on what is exchanged.

In reference to dimensions of relationships, scholars argue that relationships comprise two core dimensions (Casciaro \& Lobo, 2008; Huang \& Knight, 2017). The former is the instrumental dimension, while the latter is the emotional dimension. As for the instrumental dimension, scholars focus their attention on the "the extent to which two people are committed to and expect to benefit from advancing one another's task-relevant goals" (Huang \& Knight, 2017, p. 83). In this case, the task to be achieved and the expectations about it are the most important aspects to be considered. As for the emotional dimension, instead, scholars are interested in "the degree to which two or more subjects are committed to one another's personal and emotional welfare and hold one another in positive regard" (ibidem). In this case, personal and socio-emotional commitments and expectations are the most important aspects to be considered.

In reference to what is exchanged, Cropanzano and Mitchell (2005) identify two umbrella categories of resources: financial and social resources. Financial resources can be easily measured while social resources cannot. Among social resources, information - or, more precisely, knowledge (Cassar, 2014; Amoroso et al., 2018) - influence, and solidarity are the most cited ones (Sandefur \& Laumann, 1998).

Despite its origins in the fields of sociology and psychology, exchange theory can be very useful to investigate other fields of research, including entrepreneurship (Huang \& Knight, 2017). In fact, in order to start and manage their venture, entrepreneurs need to get financial resources. Of course, exchanges of resources depend on the relationships established between investors and entrepreneurs (Shane \& Cable, 2002; Cropanzano \& Mitchell, 2005). 
At this stage, the exchange theory generally meant needs to be referred to entrepreneurship and in particular to relationships and exchanges between investors and entrepreneurs (Fiet, 2001; Navis \& Glynn, 2011; Welter, 2012; Cherry, 2014; Maxwell \&Lévesque, 2014).

For a start, it is appropriate to restrict the application of exchange theory to the field of entrepreneurship. Not all the investors are linked to entrepreneurs by a relationship that has an instrumental and an emotional dimension. Banks, business angels, venture capitalists disclose an instrumental dimension of relationship but they do not disclose an emotional dimension (Amit et al., 1998; Brander et al., 2002; Sohl, 2003; Krasniqi, 2010; Au et al., 2016). In this case, the application of exchange theory might not be appropriate.

The investors to which the exchange theory can be easily referred are family, friends, and fools who provide love money (Ang, 1991, 1992; Bygrave et al., 2003; Brinlee et al., 2004; Austin et al., 2006; Frid, 2014; Au et al., 2016; Sieger \& Minola, 2017). The label used to identify these investors, i.e. love money, clearly underlines that both the instrumental and emotional dimensions characterize them. The task to be achieved and the expectations about it (instrumental dimension) are important but personal and socio-emotional commitments and expectations (emotional dimension) are important as well. Reasonably, there is a strong relationship at the basis of the exchange - see Welter (2012) for a critical review about trust in the entrepreneurship literature. Of course, some differences between them exist and it is worth highlighting them.

By sharing Sahlins' contribution (1965), it is possible to argue that: "close friends who start a new venture together could simultaneously have a strong emotional and instrumental relationship". Family, instead, is expected to have a strong emotional relationship but a moderate instrumental relationship. Personal and socio-emotional commitments and expectations are more important than the task to be achieved and the expectations about it (Ferry et al., 2000). On the contrary, fools are expected to have a moderate emotional relationship but a strong instrumental relationship. In this case, the task to be achieved and the expectations about it are more important than personal and socio-emotional commitments and expectations. Differences between family, friends, and fools in reference to dimensions of relationship are summed up in Table 1.

Table 1. Differences in dimensions of relationship among family, friends and fools

\begin{tabular}{lll}
\hline & Instrumental dimension & Emotional dimensions \\
\hline Family & Moderate & Strong \\
Friends & Strong & Strong \\
Fools & Strong & Moderate \\
\hline
\end{tabular}

As for what is exchanged, family, friends, and fools are expected to provide financial and social resources. All of them provide financial capital (financial investments useful to start a venture or to make it grow) but each of them provides different social resources (i.e. information, influence, and solidarity). Because of their different nature, it seems appropriate to consider information and influence on the one hand and solidarity on the other. In particular, investors and entrepreneurs share: information in the shape of knowledge about markets from which future strategies derive; reciprocal influence in the shape of recommendation and reputation; and solidarity in the shape of support and involvement (Shepherd \& Zacharakis, 2001; Cohen \& Dean, 2005; Rose, 2014). These social resources vary as the instrumental and emotional dimensions of relationships. Thus it is possible to assume that family provides moderate information and influence related to the exchange but strong solidarity. Friends provide the same solidarity as a family but they can also offer important information and have a strong influence on what is exchanged. Eventually, fools offer important information and have a strong influence on what is exchanged but they disclose moderate solidarity. Differences between family, friends, and fools in reference to what is exchanged (financial and social resources) are summed up in Table 2.

Table 2. Differences in "what is exchanged" among family, friends and fools

\begin{tabular}{llll}
\hline & Financial resources & Social resources & Solidarity \\
\cline { 3 - 4 } & & Information and influence & Strong \\
Family & Capital & Moderate & Strong \\
Friends & Capital & Important/Strong & Moderate \\
Fools & Capital & Important/Strong & \\
\hline
\end{tabular}




\section{Building the Theoretical Framework}

After recalling the definition of vocational behavior (Vondracek et al., 2014) and referring the basic assumptions of exchange theory to entrepreneurship, it is possible to depict the theoretical framework to be used for the present research.

For a start, attention is focused on the dependent variable, i.e. vocational behavior. The "core goals" seem to be the most interesting ones since they are the best examples of vocational behavior (Nichols, 1991; Henderson, 2000). They require strong commitment and involvement by individuals who try to achieve these goals. However, differently from other studies, the core goal considered herein is the survival of the firm (Suarez \& Utterback, 1995; Westhead, 1995; Agarwal, 1997; Gimeno et al., 1997; Ireland et al., 2005; Sapienza et al., 2006; Santarelli \& Vivarelli, 2007; Geroski et al., 2010; Delmar et al., 2013; Huggins et al., 2017) that can be considered a marker of efficiency achieved (Agarwal, 1997) and stands for the ability to overcome liability of smallness (Freeman et al., 1983) and of newness (Stinchcombe, 1965; Hannan \& Freeman, 1984). Differently from growth, which is affected by external factors, such as competition and dynamics of the market (Smolarski \& Kut, 2011), survival seems to depend on other factors that are innovativeness (Hyytinen et al., 2015) or support offered by stakeholder (Pajunen, 2006; Korunka et al., 2010; Kessler et al., 2012; Au et al., 2016). According to this last issue, survival of firms is a dependent variable that can be more fitting with exchange theory (investor-entrepreneur relationship) and thus it is included in the theoretical framework.

At this stage, attention can be moved on independent variables. According to Huang and Knight (2017), an exchange-based model can begin with relationships or exchanges. In reference to love money, it is assumed herein that relationships drive to exchanges of financial and social resources. In particular, it is assumed herein that exchanges of financial resources and, above all, of social resources might - in turn - affect the vocational behavior of entrepreneurs, meant as the survival of the firm. After reminding - again - that family, friend, and fools provide the same financial resources, it is important to focus on the social resources exchanged. As already said, the family provides moderate information and influence and strong solidarity. This drives to hypothesize that:

H1a: Love money provided by family is positively associated with survival of the firm.

Of course, moderate information and influence might also have a negative impact on the survival of the firm. Thus, a rival hypotheses is presented:

H1b: Love money provided by family is negatively associated with survival of the firm.

Friends provide important information and strong influence and strong solidarity. Thus, it is reasonable to hypothesize that:

H2a: Love money provided by friends is positively associated with survival of the firm.

Despite important information, strong influence and strong solidarity, it is possible that these social resources might have a negative impact on the survival of the firm. Thus, a rival hypotheses is presented:

H2b: Love money provided by friends is negatively associated with survival of the firm.

Eventually, fools provide important information and strong influence and moderate solidarity. This drives to hypothesize that:

H3a: Love money provided by fools is positively associated with survival of the firm.

Also in this case, moderate solidarity might have a negative impact on the survival of the firm. Thus, a rival hypotheses is presented:

H3b: Love money provided by fools is negatively associated with survival of the firm.

The theoretical framework used for this research (Model 1) is included in Table 3.

Table 3. The theoretical framework

\begin{tabular}{lll}
\hline Dependent variables & & Independent variable \\
\hline Love money provided by: & $\rightarrow$ & \\
Family & & Survival of the firm \\
Friends & \\
Fools & \\
\hline
\end{tabular}




\section{Methodology}

This study is based on longitudinal survey design, going from 2012 to 2014, and refers to Italy. The first year is 2012 since Italy is not included in the survey published by GEM in 2015 and referring to 2011. The last year is 2014 since it is the last survey available on the GEM website.

As for the methodology, a binomial logistic regression model is estimated for each year. The choice of a binomial logistic regression model is not arbitrary but due to the use of second-hand data retrieved from the GEM website. From available data, it is possible to know if entrepreneurs received investments from family, friends or fools and if their firms have been surviving for less or more than 42 months. This means we do not know the number of investments or the date when the firm was established. We only have information about events taking place (investments: YES or NO; survival: YES or NO). Thus, a binomial logistic regression model is the only possible choice.

According to the above, all the variables included in the framework are measured as binary variables. The dependent variable (namely the survival of the firm) is measured as a binary variable coded 0 if interviewed entrepreneurs manage and own a firm that is up to 42 months and coded 1 if interviewed entrepreneurs manage and own a firm that is older than 42 months. The threshold of 42 months is established by GEM and is agreed by management scholars (Korunka et al., 2010). Thus it is assumed valid for the present paper.

As for independent variables, love money provided by family, friends, and fools is measured as binary variables coded 0 if individuals did not receive that kind of investments and coded 1 if they did. As already stated, the present paper relies on second-hand data obtained from the GEM website. The decision to use these data entails both strengths and weaknesses. In terms of strengths, it is appropriate to underline the composition and size of the sample. As for composition, the respondents to the GEM survey are both male and female, aged between 18 and 64. The size of the sample interviewed in Italy for each year (as shown in Table 4) represents the second advantage of using GEM data. This large sample allows statistically robust results to be achieved.

Table 4. The sizes of Italian samples in 2012, 2013, and 2014

\begin{tabular}{ll}
\hline Year & Size of the sample \\
\hline 2012 & 2,000 \\
2013 & 2,052 \\
2014 & 2,000 \\
\hline
\end{tabular}

As stated above, the decision to use GEM data also entails some weaknesses. The first and foremost weakness concerns missing data, especially item non-response (i.e. when interviewees do not provide specific responses). According to Kalton and Kasprzyk (1982), this problem can be solved by an imputation procedure: estimated values, if properly inferred from the original database, can replace missing responses. Starting from the criterion that individuals who did not receive any love money answer $\mathrm{NO}=0$, otherwise they answer $\mathrm{YES}=1$, it is possible to deduce that missing responses are similar to the answer NO since they reveal a scant interest in responding to the question. In line with this, each item non-response is replaced with $\mathrm{NO}=0$. The second weakness concerns the adaptation of the data. Since data were obtained from the GEM website, they are comprehensive. However, they cannot be used to carry out additional investigations and thus further reflections or conjectures cannot be easily derived.

At this stage, before proceeding with statistical elaborations, it is important to face two main problems that might affect methodology: robustness of results and collinearity. In order to guarantee the robustness of results, it is appropriate to include some other variables (both descriptive and control variables) in the model.

As for descriptive variables, gender and age are considered. Gender is coded 0 if respondents are female entrepreneurs and 1 if respondents are male ones. Age, instead, is a continuous variable so it has been turned into categorical (three ranges of age have been considered: 18-34 years old; 35-54 years old and over 55 years old) and then into dichotomous. Age of each respondent has been assigned to one of the three categories. This is Model 2 that is going to be tested.

As for control variables, intellectual capital (made up of human, structural and relational capital) is considered herein. By definition, control variables are related to the dependent variable but from another point of view. Intellectual capital can affect the survival of the firm and so it can strengthen the robustness of results. Briefly, human capital entails competencies (knowledge and personal capabilities), attitudes (motivation and leadership) 
and intellectual agility (originality or flexibility) of entrepreneurs (MacMillan, 1986; Low \& MacMillan, 1988; Birley \& Westhead, 1993; McGrath \& MacMillan, 2000; Ucbasaran et al., 2003, 2006; Westhead et al., 2005). Structural capital refers to the competencies that companies acquire, such as patents or organizational culture (Sveiby, 1997; Bontis et al., 2000; Subramaniam \& Youndt, 2005; Cabrita \& Bontis, 2008; Wu et al., 2008; Hsu \& Fang, 2009; Hormiga et al., 2011). These competencies stand independent of the people working in those companies. Entrepreneurship scholars translate the concept of structural capital into entrepreneurial opportunities. Despite different proposals (Shane, 2000; Sarasvathy et al., 2005; Alvarez \& Barney, 2008), McMullen and Shepherd (2006) argue that some entrepreneurial opportunities are third-person opportunities since they are not linked to the person identifying them or to the context they are in. These opportunities exist by themselves and can represent structural capital in entrepreneurial studies. Eventually, relational capital refers to networking activities initiated and managed by entrepreneurs (Birley, 1985; Aldrich \& Zimmer, 1986; Johannisson, 1986, 1988; Starr \& MacMillan, 1990) and represents the value of all the relationship established with stakeholders (Bontis, 2001; Montequin et al., 2006; Cabrita \& Bontis, 2008; Wu et al., 2008; Hsu \& Fang, 2009).

GEM surveys report human, structural and relational capital as binomial variables coded 0 if entrepreneurs do not leverage on them and coded 1 if entrepreneurs do. This is Model 3 that is going to be tested.

In order to avoid collinearity among independent variables (the second problem linked to statistical elaborations), attention needs to be paid over collinearity statistics (tolerance and VIF) and over collinearity diagnostics (condition index). In Table 5, collinearity statistics about Model 3 (including independent, dependent, descriptive and control variables) are shown.

Table 5. Collinearity statistics (Value of Tolerance and VIF) about Model 3

\begin{tabular}{|c|c|c|c|c|c|c|}
\hline & 2012 & & 2013 & & 2014 & \\
\hline & Tolerance & VIF & Tolerance & VIF & Tolerance & VIF \\
\hline Family & 0.986 & 1.014 & 0.995 & 1.005 & 0.975 & 1.026 \\
\hline Friends & 0.988 & 1.012 & 0.990 & 1.010 & 0.984 & 1.016 \\
\hline Fools & 0.994 & 1.006 & 0.997 & 1.003 & 0.994 & 1.006 \\
\hline Gender & 0.966 & 1.035 & 0.944 & 1.060 & 0.989 & 1.011 \\
\hline Age (18-34) & $*$ & $*$ & 0.889 & 1.125 & $*$ & $*$ \\
\hline Age (35-54) & 0.758 & 1.320 & $*$ & $*$ & 0.733 & 1.364 \\
\hline Age (over 55) & 0.752 & 1.330 & 0.887 & 1.128 & 0.729 & 1.371 \\
\hline Human capital & 0.944 & 1.060 & 0.933 & 1.072 & 0.942 & 1.062 \\
\hline Structural capital & 0.964 & 1.037 & 0.949 & 1.054 & 0.955 & 1.047 \\
\hline Relational capital & 0.928 & 1.077 & 0.946 & 1.057 & 0.904 & 1.047 \\
\hline
\end{tabular}

According to the principles of statistics (Belsley et al., 1980), values of tolerance need to be higher than 0,50 and values of VIF need to be lower than 10 (Marquardt, 1980; Hair et al., 1995) or, even better, lower than 5 (Ringle et al., 2015). All the values included in Table 3 respect the above thresholds.

In order to be sure that there is no collinearity among independent variables, it is appropriate to calculate the condition index, a value included among collinearity diagnostics about model 3 (including independent, dependent, descriptive and control variables). Values are shown in Table 6. 
Table 6. Collinearity diagnostics (Condition Index) about Model 3.

\begin{tabular}{llll}
\hline & 2012 & 2013 & 2014 \\
\hline Constant & 1.000 & 1.000 & 1.000 \\
Family & 1.786 & 1.794 & 1.841 \\
Friends & 1.818 & 1.825 & 1.869 \\
Fools & 1.833 & 1.834 & 1.877 \\
Gender & 1.868 & 1.853 & 1.901 \\
Age (18-34) & $*$ & 1.980 & $*$ \\
Age (35-54) & 2.096 & $*$ & 2.208 \\
Age (over 55) & 2.199 & 2.157 & 2.297 \\
Human capital & 2.391 & 2.320 & 2.516 \\
Structural capital & 2.909 & 3.020 & 2.862 \\
Relational capital & 4.857 & 8.796 & 5.237 \\
$*$ Variables excluded from SPS. & & & \\
\hline
\end{tabular}

According to the principles of statistics, values of condition index higher than thirty disclose strong collinearity; values comprehended between fifteen and thirty reveal suspected collinearity; values lower than fifteen do not show any collinearity among independent variables. As shown by values included in Table 6, there is no collinearity among independent variables.

At this stage, it is possible to elaborate binomial logistic regression models. Elaborations have been conducted using a forward Wald approach (see Tables 7,8 and 9).

Table 7. Estimated Logit models of love money affecting survival of firms in Italy in 2012

\begin{tabular}{|c|c|c|c|}
\hline & Model 1 & Model 2 & Model 3 \\
\hline Constant & $0.035(0.000)$ & $0.035(0.000)$ & $0.021(0.000)$ \\
\hline Family & $0.322(0.571)$ & $0.322(0.571)$ & $0.167(0.683)$ \\
\hline Friends & $0.496(0.481)$ & $0.496(0.481)$ & $0.657(0.418)$ \\
\hline Fools & $0.478(0.489)$ & $0.478(0.489)$ & $0.121(0.728)$ \\
\hline Gender & & $3.646(0.056)$ & $2.353(0.125)$ \\
\hline Age (18-34) & & $2.993(0.084)$ & $3.556(0.059)$ \\
\hline Age $(35-54)$ & & $3.092(0.079)$ & $2.244(0.134)$ \\
\hline Age (over 55) & & $0.034(0.853)$ & $0.127(0.722)$ \\
\hline Human capital & & & $3.458(0.021)$ \\
\hline Structural capital & & & $0.633(0.426)$ \\
\hline Relational capital & & & $0.129(0.741)$ \\
\hline Number of cases & 2,000 & 2,000 & 2,000 \\
\hline$\%$ of correct predictions & 96.6 & 96.6 & 96.6 \\
\hline$\chi^{2}$ of Omnibus test - OT & - & - & 24.567 \\
\hline $\mathrm{OT}$ - degree of freedom & - & - & 1 \\
\hline Nagelkerke $R^{2}$ (pseudo $R^{2}$ ) & - & - & 0.048 \\
\hline
\end{tabular}

Table 8. Estimated Logit models of love money affecting survival of firms in Italy in 2013

\begin{tabular}{|c|c|c|c|}
\hline & Model 1 & Model 2 & Model 3 \\
\hline Constant & $0.036(0.000)$ & $0.158(0.000)$ & $0.050(0.000)$ \\
\hline Family & $5.928(0.006)$ & $4.811(0.020)$ & $6.001(0.008)$ \\
\hline Friends & $1.560(0.212)$ & $0.584(0.445)$ & $0.038(0.846)$ \\
\hline Fools & $0.072(0.788)$ & $0.164(0.685)$ & $0.074(0.785)$ \\
\hline Gender & & $0.242(0.000)$ & $0.335(0.000)$ \\
\hline Age (18-34) & & $0.011(0.917)$ & $0.090(0.765)$ \\
\hline Age (35-54) & & $2.148(0.003)$ & $2.192(0.003)$ \\
\hline Age (over 55) & & $0.011(0.917)$ & $0.090(0.765)$ \\
\hline Human capital & & & $1.687(0.039)$ \\
\hline Structural capital & & & $2.069(0.007)$ \\
\hline Relational capital & & & $2.956(0.000)$ \\
\hline Number of cases & 2,052 & 2,052 & 2,052 \\
\hline$\%$ of correct predictions & 96.4 & 96.4 & 96.4 \\
\hline$\chi^{2}$ of Omnibus test - OT & 5.201 & 45.316 & 81.351 \\
\hline OT - degree of freedom & 1 & 3 & 6 \\
\hline Nagelkerke $\mathrm{R}^{2}$ (pseudo $\mathrm{R}^{2}$ ) & 0.009 & 0.082 & 0.146 \\
\hline
\end{tabular}


Table 9. Estimated Logit models of love money affecting survival of firms in Italy in 2014

\begin{tabular}{|c|c|c|c|}
\hline & Model 1 & Model 2 & Model 3 \\
\hline Constant & $0.042(0.000)$ & $0.029(0.000)$ & $0.016(0.000)$ \\
\hline Family & $3.392(0.052)$ & $3.819(0.051)$ & $1.280(0.258)$ \\
\hline Friends & $5.587(0.002)$ & $5.075(0.004)$ & $3.191(0.049)$ \\
\hline Fools & $1.901(0.168)$ & $2.310(0.129)$ & $1.394(0.238)$ \\
\hline Gender & & $1.974(0.003)$ & $1.819(0.011)$ \\
\hline Age (18-34) & & $2.249(0.134)$ & $3.728(0.054)$ \\
\hline Age $(35-54)$ & & $0.755(0.385)$ & $0.854(0.355)$ \\
\hline Age (over 55) & & $0.388(0.533)$ & $1.255(0.263)$ \\
\hline Human capital & & & $2.875(0.000)$ \\
\hline Structural capital & & & $0.257(0.613)$ \\
\hline Relational capital & & & $1.830(0.010)$ \\
\hline Number of cases & 2,000 & 2,000 & 2,000 \\
\hline$\%$ of correct predictions & 95.7 & 95.7 & 95.7 \\
\hline$\chi^{2}$ of Omnibus test - OT & 9.182 & 15.380 & 49.489 \\
\hline $\mathrm{OT}$ - degree of freedom & 2 & 2 & 4 \\
\hline Nagelkerke $R^{2}$ (pseudo $R^{2}$ ) & 0.015 & 0.026 & 0.082 \\
\hline
\end{tabular}

\section{Discussion and Conclusions}

From Tables 7, 8 and 9, very intriguing results come out about the influence that love money can have on the survival of firms (statistically significant results are bold-typed). In reference to 2012 (whose results are included in Table 7), love money does not affect the survival of entrepreneurial firms. In reference to 2013 (see Table 8), only love money provided by families affects the survival of firms launched by female entrepreneurs aged between 35-54 who can leverage intellectual capital (human, structural and relational capital). Eventually, in reference to 2014 (see Table 9), only love money provided by friends affects the survival of firms launched by male entrepreneurs who can leverage human and relational capital.

Achieved results need to be properly commented even if different perspectives need to be adopted. For a start, in reference to the kind of investments, it results that love money provided by fools does not affect the survival of firms and so vocational behavior. The moderate emotional dimension and moderate solidarity seem to prevail over the strong instrumental dimension and the important information and strong influence. As a result, entrepreneurs do not feel supported by fools. Different results, instead, are achieved when family and friends provide love money. Both of them affect in a positive way vocational behavior, even if the intensity of this support varies across them. As already said, families show a strong emotional dimension and strong solidarity even if - at the same time - they show a moderate instrumental dimension and moderate information and influence. Emotional dimensions and solidarity are very important: if families provide love money, then vocational behavior towards "core goals" is more effective (the coefficient is 6.001). This confirms the relevance of support provided by the family. As for friends, they disclose strong instrumental and emotional dimensions on the one hand and important information and strong influence and solidarity on the other one. Despite this, if friends provide love money, then vocational behavior towards core goals is strong (the coefficient is 3.191) but it less strong than in the case of family support. These results, that could be obvious for some readers in some countries, are totally in contrast with previous studies. In reference to Norway, for example, Erikson et al. (2003) argue that family and friends generally invest in firms that show a higher failure rate and lower performances.

Achieved results also show that vocational behavior depends on the profile of entrepreneurs. Descriptive and control variables included in the theoretical model help to draw these profiles. Love money provided by family affects vocational behavior of female entrepreneurs aged between 35-54 who can leverage intellectual capital (human, structural and relational capital). Beyond human, structural and relational capital they hold and can exploit, female entrepreneurs perceive emotional dimensions and solidarity as the main drivers of their choices. Intellectual capital and family support push them to maximize their involvement in entrepreneurial activities. This result confirms and enriches the copious literature investigating the role of gender in the investor-entrepreneur relationship and its impact on entrepreneurial involvement (Alsos \& Ljunggren, 2017; Malmström et al., 2017).

At the same time, love money provided by friends affects the vocational behavior of male entrepreneurs who can leverage human and relational capital. Not only emotional dimensions and solidarity but also important information and strong influence and solidarity got by friends affect the vocational behavior of male entrepreneurs who do not leverage structural capital. Reasonably, it can be hypothesized that friends supply information that balance out the missing of structural capital. 
Based on the findings of this study, love money provided by family and friends affects the vocational behavior of Italian entrepreneurs. Despite some differences (related to the entrepreneurial profile), it results that emotional dimensions and solidarity are at the basis of a stronger vocational behavior. In this vein, achieved results confirm that idea that socio-psychological factors affect entrepreneurial financing decisions (Au et al., 2016) and - above all - that capital provided by family and friends is a sort of "poisoned gift" (Sieger \& Minola, 2017). Even if the scholars use this label only in reference to the family (and here it is referred to friends as well), what matters is the idea that these kinds of informal capital are a gift since they support the entrepreneurial activity, but they are poisoned since they imply "embeddedness and related obligations" (ibidem, pg. 180). In the present study, these aspects affect - in a strong way - vocational behavior.

Of course, more data and further investigations would be necessary in order to disclose more insights and strengthen achieved results. In this vein, some limitations need to be underlined. The paper relies on second-hand data that do not comprehend some aspects that might enrich the analysis (other variables to be included, such as the amount of investment provided) and refers to only one country over a limited time span. However, because of the explorative nature of this research, these limitations do not seem to invalidate achieved results. Actually, they seem to suggest some extensions.

First, entrepreneurship researchers might extend the considered time-span or they might refer to a larger sample of Italian entrepreneurs. New results might come out about the impact that love money can have on vocational behavior in Italy.

Second, entrepreneurship scholars might replicate the same research in different contexts. This could help to verify whether different socio-economic contexts (in which investors might perceive both instrumental and emotional dimensions and information and influence and solidarity in a different way) and cultures can affect vocational behavior.

Of course, and this stands for the third option, entrepreneurship researchers might start a national or cross-national survey to collect specific new data about love money and vocational behavior. In this case, the limitations deriving from the use of second-hand data could be eliminated and hence more robust results might be disclosed about the influence of love money on vocational behavior.

\section{Acknowledgments}

Although this article is the result of a joint effort of analysis and reflections, DM authored sections 2, 3, 4 and 5 and MS authored section 1. Both the authors read and approved the final manuscript.

\section{References}

Agarwal, R. (1997). Survival of firms over the product life cycle. Southern Economic Journal, 63(3), 571-584. https://doi.org/10.2307/1061095

Aldrich, H. E., \& Zimmer, C. (1986). Entrepreneurship through social networks. In H. E. Aldrich (Ed.), Population Perspective on Organizations (pp. 13-28). Uppsala: Acta Universitatis Upaliensis.

Alsos, G. A., \& Ljunggren, E. (2017). The role of gender in entrepreneur-investor relationships: A signaling theory approach. Entrepreneurship: Theory and Practice, 41(4), 567-590. https://doi.org/10.1111/etp.12226

Alvarez, S. A., \& Barney, J. B. (2008). Opportunities, organizations, and entrepreneurship. Strategic Entrepreneurship Journal, 2(4), 171-173. https://doi.org/10.1002/sej.52

Amit, R., Brander, J., \& Zott, C. (1998). Why do venture capital firms exist? Theory and Canadian evidence. Journal of Business Venturing, 13(6), 441-466.

Amoroso, S., Audretsch, D. B., \& Link, A. N. (2018). Sources of knowledge used by entrepreneurial firms in the European high-tech sector. Eurasian Business Review, 8(1), 55-70. https://doi.org/10.1016/S0883-9026(97)00061-X

Ang, J. S. (1991). Small Business Uniqueness and the Theory of Financial Management. The Journal of Entrepreneurial Finance, 1(1), 11-13.

Ang, J. S. (1992). On the Theory of Finance for Privately Held Firms. Journal of Small Business Finance, 1(3), 185-203.

Au, K., Chiang, F. F., Birtch, T. A., \& Kwan, H. K. (2016). Entrepreneurial financing in new business ventures: a help-seeking behavior perspective. International Entrepreneurship and Management Journal, 12(1), 199-213. https://doi.org/10.1007/s11365-014-0332-5

Austin, J., Stevenson, H., \& Wei-Skillern, J. (2006). Social and commercial entrepreneurship: same, different, or 
both?. Entrepreneurship: Theory and Practice, 30, 1-22. https://doi.org/10.5700/rausp1055

Bellavitis, C., Filatotchev, I., Kamuriwo, D. S., \& Vanacker, T. (2017). Entrepreneurial finance: new frontiers of research and practice: Editorial for the special issue Embracing entrepreneurial funding innovations. Venture Capital, 19, 1-16. https://doi.org/10.1080/13691066.2016.1259733

Belsley, D. A., Kuh, D., \& Welsch, R .E. (1980). Regression Diagnostics. New York, NY: John Wiley.

Birley, S. (1985). The role of networks in the entrepreneurial process. Journal of Business Venturing, 1(1), 107-117. https://doi.org/10.1016/0883-9026(85)90010-2

Birley, S., \& Westhead, P. (1993). A comparison of new business established by novice and habitual founders in Great Britain. International Small Business Journal, 12(1), 38-60. https://doi.org/10.1177/0266242693121003

Blau, P. (1964). Exchange and power in social life. New York, NY: John Wiley.

Bontis, N. (2001). Assessing knowledge assets: a review of the models used to measure intellectual capital. International Journal of Management Reviews, 3(1), 41-60. https://doi.org/10.1111/1468-2370.00053

Bontis, N., Keow, W. C. C., \& Richardson, S. (2000). Intellectual capital and business performance in Malaysian industries. Journal of Intellectual Capital, 1(1), 85-100. https://doi.org/10.1108/14691930010324188

Brander, J. A., Amit, R., \& Antweiler, W. (2002). Venture-capital syndication: Improved venture selection vs. the value-added hypothesis. Journal of Economics \& Management Strategy, 11(3), 423-452. https://doi.org/10.1111/j.1430-9134.2002.00423.x.

Bright, J. E., \& Pryor, R. G. (2011). The chaos theory of careers. Journal of Employment Counseling, 48(1), 163-166. https://doi.org/10.1002/j.2161-1920.2011.tb01104.x

Brinlee, J. B., Franklin, G. M., Bell, J. R., \& Bullock, C. A. (2004). Educating entrepreneurs on angel venture capital financing options. Journal of Business and Entrepreneurship, 16(2), 141-156.

Busenitz, L., \& Lau, C. (1996). A cross-cultural cognitive model of new venture creation. Entrepreneurship: Theory and Practice, 20(4), 25-39. https://doi.org/10.1177/104225879602000403

Busenitz, L., Gomez, C., \& Spencer, J. W. (2000). Country Institutional Profiles: Unlocking Entrepreneurial Phenomena. The Academy of Management Journal, 43(5), 994-1003. https://doi.org/10.5465/1556423

Bygrave, W., Hay, M., Ng, E., \& Reynolds, P. (2003). Executive forum: A study of informal investing in 29 nations com- posing the Global Entrepreneurship Monitor. Venture Capital, 5(2), 101-116. https://doi.org/10.1080/1369106032000097021

Cabrita, M. D. R., \& Bontis, N. (2008). Intellectual capital and business performance in the Portuguese banking industry. International Journal of Technology Management, 43(1-3), 212-237.

Casciaro, T., \& Lobo, M. S. (2008). When competence is irrelevant: The role of interpersonal affect in task-related ties. Administrative Science Quarterly, 53(4), 655-684. https://doi.org/10.2189/asqu.53.4.655

Cassar, G. (2014). Industry and startup experience on entrepreneur forecast performance in new firms. Journal of Business Venturing, 29(1), 137-151. https://doi.org/10.1016/j.jbusvent.2012.10.002

Cherry, B. (2014). Entrepreneur as trust-builder: interaction frequency and relationship duration as moderators of the factors of perceived trustworthiness. International Journal of Business and Globalisation, 14(1), $97-121$.

Cohen, B. D., \& Dean, T. J. (2005). Information asymmetry and investor valuation of IPOs: Top management team legitimacy as a capital market signal. Strategic Management Journal, 26(7), 683-690. https://doi.org/10.1002/smj.463

Cropanzano, R., \& Mitchell, M. S. (2005). Social exchange theory: An interdisciplinary review. Journal of Management, 31(6), 874-900. https://doi.org/10.1177/0149206305279602

Delmar, F., McKelvie, A., \& Wennberg, K. (2013). Untangling the relationships among growth, profitability and survival in new firms. Technovation, 33(8-9), 276-291. https://doi.org/10.1016/j.technovation.2013.02.003

Ehrlich, S. B., De Noble, A. F., Moore, T., \& Weaver, R. R. (1994). After the cash arrives: A comparative study of venture capital and private investor involvement in entrepreneurial firms. Journal of Business Venturing, 9(1), 67-82. https://doi.org/10.1016/0883-9026(94)90027-2

Emerson, R. M. (1976). Social exchange theory. Annual Review of Sociology, 2(1), 335-362. 
Erikson, T., Sørheim, R., \& Reitan, B. (2003). Family angels vs. other informal investors. Family Business Review, 16(3), 163-171. https://doi.org/10.1111/j.1741-6248.2003.tb00011.x

Ferry, T. R., Fouad, N. A., \& Smith, P. L. (2000). The role of family context in a social cognitive model for career-related choice behavior: A math and science perspective. Journal of Vocational Behavior, 57(3), 348-364. https://doi.org/10.1006/jvbe.1999.1743

Fiet, J. O. (2001). The theoretical side of teaching entrepreneurship. Journal of Business Venturing, 16(1), 1-24. https://doi.org/10.1016/S0883-9026(99)00041-5

Freeman, J., Carroll, G. R., \& Hannan, M. T. (1983). The liability of newness: Age dependence in organizational death rates. American Sociological Review, 48, 692-710. https://doi.org/10.2307/2094928

Frid, C. J. (2014). Acquiring financial resources to form new ventures: the impact of personal characteristics on organizational emergence. Journal of Small Business \& Entrepreneurship, 27(3), 323-341. https://doi.org/10.1080/08276331.2015.1082895

George, G., \& Zahra, S. A. (2002). Culture and its consequences for entrepreneurship. Entrepreneurship: Theory and Practice, 26(4), 5-8. https://doi.org/10.1177/104225870202600401

Geroski, P. A., Mata, J., \& Portugal, P. (2010). Founding conditions and the survival of new firms. Strategic Management Journal, 31(5), 510-529. https://doi.org/10.1002/smj.823

Gimeno, J., Folta, T. B., Cooper, A. C., \& Woo, C. Y. (1997). Survival of the fittest? Entrepreneurial human capital and the persistence of underperforming firms. Administrative Science Quarterly, 42, 750-783. https://doi.org/10.2307/2393656

Hair, J. F. Jr., Anderson, R. E., Tatham, R. L., \& Black, W. C. (1995). Multivariate Data Analysis (3rd ed). New York: Macmillan.

Hannan, M. T., \& Freeman, J. (1984). Structural inertia and organizational change. American Sociological Review, 49, 149-164. https://doi.org/10.2307/2095567

Henderson, S. J. (2000). Follow your bliss: A process for career happiness. Journal of Counseling \& Development, 78(3), 305-315. https://doi.org/10.1002/j.1556-6676.2000.tb01912.x

Homans, G. (1958). Social behavior as exchange. American Journal of Sociology, 63(6), 597-606.

Hormiga, E., Batista-Canino, R. M., \& Sánchez-Medina, A. (2011). The role of intellectual capital in the success of new ventures. International Entrepreneurship and Management Journal, 7(1), 71-92. https://doi.org/10.1007/s11365-010-0139-y

Hsu, Y. H., \& Fang, W. (2009). Intellectual capital and new product development performance: the mediating role of organizational learning capability. Technological Forecasting and Social Change, 76(5), 664-677. https://doi.org/10.1016/j.techfore.2008.03.012

Huang, L., \& Knight, A. P. (2017). Resources and relationships in entrepreneurship: an exchange theory of the development and effects of the entrepreneur-investor relationship. Academy of Management Review, 42(1), 80-102. https://doi.org/10.5465/amr.2014.0397

Huggins, R., Prokop, D., \& Thompson, P. (2017). Entrepreneurship and the determinants of firm survival within regions: human capital, growth motivation and locational conditions. Entrepreneurship \& Regional Development, 29(3-4), 357-389. https://doi.org/10.1080/08985626.2016.1271830

Hyytinen, A., Pajarinen, M., \& Rouvinen, P. (2015). Does innovativeness reduce startup survival rates? Journal of Business Venturing, 30(4), 564-581. https://doi.org/10.1016/j.jbusvent.2014.10.001

Ireland, R. D., Reutzel, C. R., \& Webb, J. W. (2005). Entrepreneurship research in AMJ: What has been published, and what might the future hold? Academy of Management Journal, 48(4), 556-564. https://doi.org/10.5465/amj.2005.17843937

Johannisson, B. (1986). Network strategies: management technology for entrepreneurship and change. International Small Business Journal, 5(1), 19-30. https://doi.org/10.1177/026624268600500102

Johannisson, B. (1988). Business formation: a network approach. Scandinavian Journal of Management, 4(3-4), 83-99. https://doi.org/10.1016/0956-5221(88)90002-4

Kalton, G., \& Kasprzyk, D. (1982, August). Imputing for missing survey responses. In Proceedings of the section on survey research methods, American Statistical Association, American Statistical Association Cincinnati. 
Kessler, A., Korunka, C., Frank, H., \& Lueger, M. (2012). Predicting founding success and new venture survival: A longitudinal nascent entrepreneurship approach. Journal of Enterprising Culture, 20(1), 25-55. https://doi.org/10.1142/S0218495812500021

Korunka, C., Kessler, A., Frank, H., \& Lueger, M. (2010). Personal characteristics, resources, and environment as predictors of business survival. Journal of Occupational and Organizational Psychology, 83(4), 1025-1051. https://doi.org/10.1348/096317909X485135

Kotha, R., \& George, G. (2012). Friends, family, or fools: Entrepreneur experience and its implications for equity distribution and resource mobilization. Journal of Business Venturing, 27(5), 525-543. https://doi.org/10.1016/j.jbusvent.2012.02.001

Krasniqi, B. A. (2010). Are small firms really credit constrained? Empirical evidence from Kosova. International Entrepreneurship and Management Journal, 6(4), 459-479. https://doi.org/10.1007/s11365-010-0135-2

Low, M. B., \& MacMillan, I. C. (1988). Entrepreneurship: past research and future challenges. Journal of Management, 14(2), 139-162. https://doi.org/10.1177/014920638801400202

MacMillan, I. C. (1986). To really know about entrepreneurship, let's study habitual entrepreneur. Journal of Business Venturing, 1(1), 241-243.

Malmström, M., Johansson, J., \& Wincent, J. (2017). Gender stereotypes and venture support decisions: how governmental venture capitalists socially construct entrepreneurs' potential. Entrepreneurship: Theory and Practice, 41(5), 833-860. https://doi.org/10.1111/etap.12275

Marquardt, D. W. (1980). You should standardize the predictor variables in your regression models. Discussion of: A critique of some ridge regression methods. Journal of the American Statistical Association, 75(369), 87-91.

Maxwell, A. L., \& Lévesque, M. (2014). Trustworthiness: A critical ingredient for entrepreneurs seeking investors. Entrepreneurship Theory and Practice, 38(5), 1057-1080. https://doi.org/10.1111/j.1540-6520.2011.00475.x

McGrath, R. G., \& Macmillan, I. C. (2000), The Entrepreneurial Mindset. Boston (MA): Harvard Business School Press.

McMullen, J. S., \& Shepherd, D. (2006). Entrepreneurial action and the role of uncertainty in the theory of the entrepreneur. Academy of Management Review, 31(1), 132-152. https://doi.org/10.5465/amr.2006.19379628

Mitchell, R. K., Busenitz, L., Lant, T., Mcdougall, P. P., Morse, E. A., \& Smith, J. B. (2002). Toward a theory of entrepreneurial cognition: rethinking the people side of entrepreneurial research. Entrepreneurship: Theory and Practice, 27(2), 93-104. https://doi.org/10.1111/1540-8520.00001

Mitchell, R. K., Smith, B., Seawright, K., \& Morse, E. (2000). Cross-cultural cognitions and the venture creation process. Academy of Management Review, 43(5), 974-993. https://doi.org/10.5465/1556422

Montequin, V. R., Fernández, F. O., Cabal, V. A., \& Gutierrez, N. R. (2006). An integrated framework for intellectual capital measurement and knowledge management implementation in small and medium-sized enterprises. Journal of Information Science, 32(6), 525-538. https://doi.org/10.1177/0165551506067127

Mueller, S. L., \& Thomas, A. S. (2001). Culture and entrepreneurial potential: a nine country study of locus of control and innovativeness. Journal of Business Venturing, 16(1), 51-75. https://doi.org/10.1016/S0883-9026(99)00039-7

Navis, C., \& Glynn, M. A. (2011). Legitimate distinctiveness and the entrepreneurial identity: Influence on investor judgments of new venture plausibility. Academy of Management Review, 36(3), 479-499. https://doi.org/10.5465/amr.2008.0361

Nichols, C. W. (1991). Manual: Assessment of core goals. Palo Alto, CA: Consulting.

Pajunen, K. (2006). Stakeholder influences in organizational survival. Journal of Management Studies, 43(6), 1261-1288. https://doi.org/10.1111/j.1467-6486.2006.00624.x

Patton, W., \& McMahon, M. (2006). The systems theory framework of career development and counselling: Connecting theory and practice. International Journal for the Advancement of Counselling, 28(2), 153-166. https://doi.org/10.1007/s10447-005-9010-1

Ringle, C. M., Wende, S., \& Becker, J. M. (2015). SmartPLS 3. Bönningstedt: SmartPLS. Retrieved from http:/www.smartpls.com 
Rose, D. S. (2014). Angel investing: The gust guide to making money and having fun investing in startups. Hoboken, NJ: Wiley.

Sahlins, M. (1965). Exchange value and the diplomacy of primitive trade. In J. Helm, P. Bohannan, \& M. D. Sahlins (Eds.), Essays in economic anthropology: Dedicated to the memory of Karl Polanyi (pp. 95-129). Seattle: University of Washington Press.

Sandefur, R. L., \& Laumann, E. O. (1998). A paradigm for social capital. Rationality and Society, 10, 481-501. https://doi.org/10.1177/104346398010004005

Santarelli, E., \& Vivarelli, M. (2007). Entrepreneurship and the process of firms' entry, survival and growth. Industrial and Corporate Change, 16(3), 455-488. https://doi.org/10.1093/icc/dtm010

Sapienza, H. J., \& Korsgaard, M. A. (1996). Procedural justice in entrepreneur-investor relations. Academy of Management Journal, 39(3), 544-574. https://doi.org/10.5465/256655

Sapienza, H. J., Autio, E., George, G., \& Zahra, S. A. (2006). A capabilities perspective on the effects of early internationalization on firm survival and growth. Academy of Management Review, 31(4), 914-933. https://doi.org/10.5465/amr.2006.22527465

Sarasvathy, S. D., Dew, N., Velamuri, S. R., \& Venkataraman, S. (2005). Three views ofentrepreneurial opportunity. In Z. J. Acs, \& D. B.Audretsch (Eds), Handbook of Entrepreneurship Research: An Interdisciplinary Survey and Introduction (pp. 141-160). New York: Springer.

Savickas, M. L. (2002). Reinvigorating the study of careers. Journal of Vocational Behavior, 61(3), 381-385. https://doi.org/10.1006/jvbe.2002.1880

Savickas, M. L. (2005). The theory and practice of career construction. In S. D. Brown, \& R. W. Lent (eds.), Career development and counseling: Putting theory and research to work (pp. 42-70), New York: John Wiley and Sons.

Shane, S. (2000). Prior knowledge and the discovery of entrepreneurial opportunities. Organization Science, 11(4), 448-469. https://doi.org/10.1287/orsc.11.4.448.14602

Shane, S., \& Cable, D. (2002). Network ties, reputation, and the financing of new ventures. Management Science, 48(3), 364-381. https://doi.org/10.1287/mnsc.48.3.364.7731

Shepherd, D. A., \& Zacharakis, A. 2001. The venture capitalist-entrepreneur relationship: Control, trust and confidence in co-operative behaviour. Venture Capital, 3(2), 129-149. https://doi.org/10.1080/13691060110042763

Sieger, P., \& Minola, T. (2017). The family's financial support as a "Poisoned gift": A family embeddedness perspective on entrepreneurial intentions. Journal of Small Business Management, 55, 179-204. https://doi.org/10.1111/jsbm.12273

Smolarski, J., \& Kut, C. (2011). The impact of venture capital financing method on SME performance and internationalization. International Entrepreneurship and Management Journal, 7(1), 39-55. https://doi.org/10.1007/s11365-009-0128-1

Sohl, J. E. (2003). The U.S. angel and venture capital market: Recent trends and developments. Journal of Private Equity, 6(2), 7-17.

Starr, J. A., \& Macmillan, I. C. (1990), Resource cooptation via social contracting: resource acquisition strategies for new ventures. Strategic Management Journal, 11, 79-92.

Steiner, L., \& Greenwood, R. (1995). Venture capital relationships in the deal structuring and post-investment stages of firm creation. Journal of Management Studies, 32(3), 337-357. https://doi.org/10.1111/j.1467-6486.1995.tb00779.x

Stinchcombe, A. L. (1965). Social structure and organizations. In J. G. March (ed.), Handbook of organizations (pp. 142-193). New York, NY: Routledge.

Suarez, F. F., \& Utterback, J. M. (1995). Dominant designs and the survival of firms. Strategic Management Journal, 16(6), 415-430. https://doi.org/10.1002/smj.4250160602

Subramaniam, M., \& Youndt, M. A. (2005). The influence of intellectual capital on the type of innovative capabilities. Academy of Management Journal, 48(3), 450-463. https://doi.org/10.5465/amj.2005.17407911

Sveiby, K. E. (1997). The New Organizational Wealth: Managing and Measuring Knowledge Based Assets. San Francisco, CA: Berrett Koehler. 
Ucbasaran, D., Westhead, P., \& Wright, M. (2006), The Habitual Entrepreneur, Aldershot: Edward Elgar Publishing Ltd.

Ucbasaran, D., Wright, M., \& Westhead, P. (2003). A longitudinal study of habitual entrepreneurs: starters and acquirers. Entrepreneurship \& Regional Development, 15(3), 207-228. https://doi.org/10.1080/08985620210145009

Valach, L., \& Young, R. A. (2004). Some cornerstones in the development of a contextual action theory of career and counselling. International Journal for Educational and Vocational Guidance, 4(1), 61-81. https://doi.org/10.1023/B:IJVO.0000021138.12299.cf

Vondracek, F. W., \& Schulenberg, J. E. (1986). Career development in adolescence: Some conceptual and intervention issues. The Career Development Quarterly, 34(4), 247-254. http://dx.doi.org/10.1002/j.2164-585X.1986.tb00860.x

Vondracek, F. W., Ford, D. H., \& Porfeli, E. J. (2014). A living systems theory of vocational behavior and development. In F. W. Vondracek, D. H. Ford, \& E. J. Porfeli (Eds.), A living systems theory of vocational behavior and development (pp. 55-80). Rotterdam: SensePublishers.

Welter, F. (2012). All you need is trust? A critical review of the trust and entrepreneurship literature. International Small Business Journal, 30(3), 193-212. https://doi.org/10.1177/0266242612439588

Westhead, P. (1995). Survival and employment growth contrasts between types of owner-managed high-technology firms. Entrepreneurship: Theory and Practice, 20(1), 5-27. https://doi.org/10.1177/104225879502000101

Westhead, P., Ucbasaran, D., \& Wright, M. (2005). Decisions, actions and performances: do novice, serial and portfolio entrepreneurs differ?. Journal of Small Business Management, 43(4), 393-417. https://doi.org/10.1111/j.1540-627X.2005.00144.x

Wu, W., Chang, M., \& Chen, C. (2008). Promoting innovation through the accumulation of intellectual capital, social capital and entrepreneurial orientation. R\&D Management, 38(3), 265-277. https://doi.org/10.1111/1467-9914.00120-i1

Young, R. A., \& Valach, L. (2000). 12 Reconceptualising career theory and research: an action-theoretical perspective. In A. Collin, \& R. A. Young (Eds.), The future of career (pp. 181-196). New York: Cambridge University Press.

Young, R. A., \& Valach, L. (2008). Action theory: an integrative paradigm for research and evaluation in career. In J. A. Athanasou, \& R. Van Esbroeck (Eds.), International Handbook of Career Guidance (pp. 643-657). Dordrecht: Springer.

\section{Copyrights}

Copyright for this article is retained by the author(s), with first publication rights granted to the journal.

This is an open-access article distributed under the terms and conditions of the Creative Commons Attribution license (http://creativecommons.org/licenses/by/4.0/). 